Images in ...

\title{
Postpartum headache: sinus venous thrombosis
}

\author{
Angel Estella, ${ }^{1}$ Jose Luis Payares ${ }^{2}$
}

${ }^{1}$ Department of Emergency, Hospital SAS de Jerez, Jerez de la Frontera, Spain

${ }^{2}$ Department of Radiology, Hospital SAS de Jerez, Jerez de la Frontera, Spain

Correspondence to Angel Estella, litoestella@hotmail.com

\section{DESCRIPTION}

A 25-year-old woman with a personal history of a recent epidural anaesthesia for vaginal delivery. Four days later was attended in the emergency department by persistent headache. In the physical examination there was not nuchal rigidity nor neurological abnormalities. Initially hydration, analgesic drugs and lying down with bed rest were the treatment for a suspected postdural puncture headache. Due to a lack of relieve with this treatment an urgent brain CT scan was performed because of MRI was not available. It showed a cerebral venous sinus thrombosis (figures 1-3). The patient was admitted in the intensive care unit (ICU) and was treated with systemic anticoagulation therapy with continuous intravenous heparin sodium, during the admission the patient started to improve and after 4 days was discharged to the neurology ward. Three months after

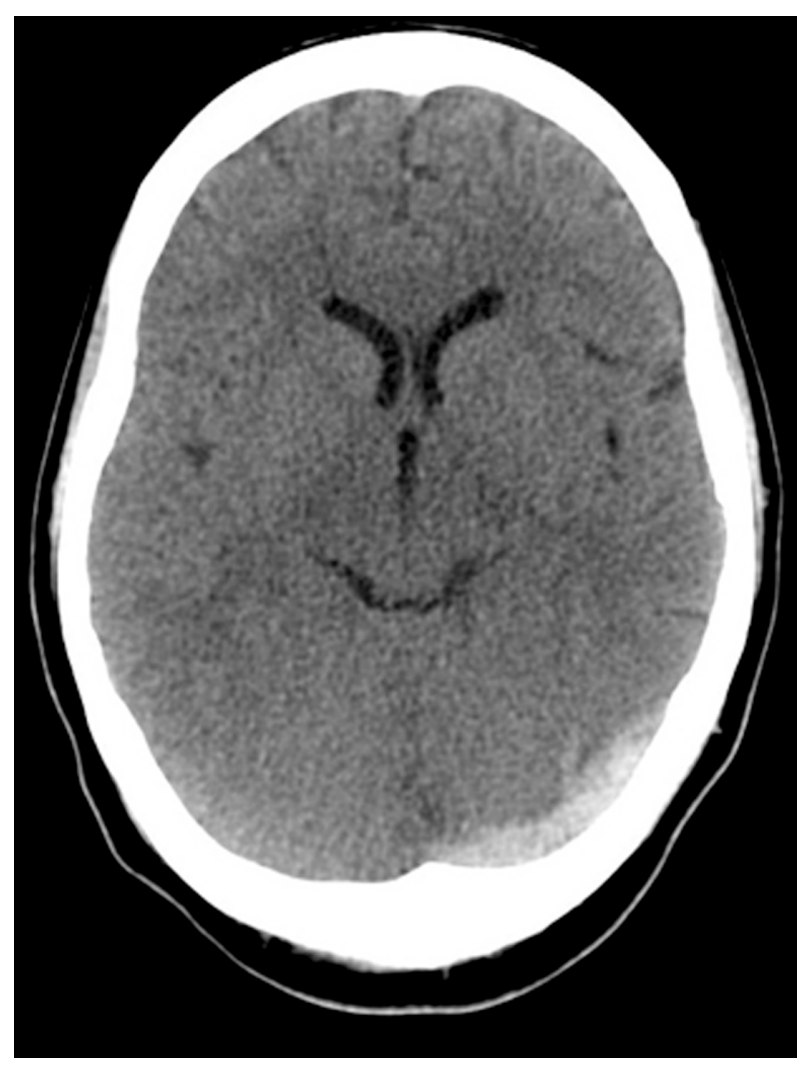

Figure 1 Non-contrast enhanced computed axial cranial tomography. Non-enhanced CT with a focus of hyperdensity within the occluded sinus.
ICU discharge neurologist indicated to perform thrombophilic tests: lupus anticoagulant, anticardiolipin antibody, complete blood count, prothrombin time, partial thromboplastin time, thrombin time, fibrinogen test, factor $\mathrm{V}$ Leiden, protein $\mathrm{S}$ and protein $\mathrm{C}, \mathrm{D}$ dimer, homocysteine levels and factor V Leiden and G20210A mutation of prothrombin gene. Normal laboratory test results were obtained.

Postdural puncture headache developed within $48 \mathrm{~h}$ of the epidural anaesthesia, typically symptoms improve with rest in a supine position avoiding standing or raising the head from the bed. The lack of response to treatment led to perform a brain CT scan to rule out other causes of puerperium headaches.

Pregnancy-induced hypertension, migraine, intracranial bleed, cerebral vein thrombosis, cerebral tumour and

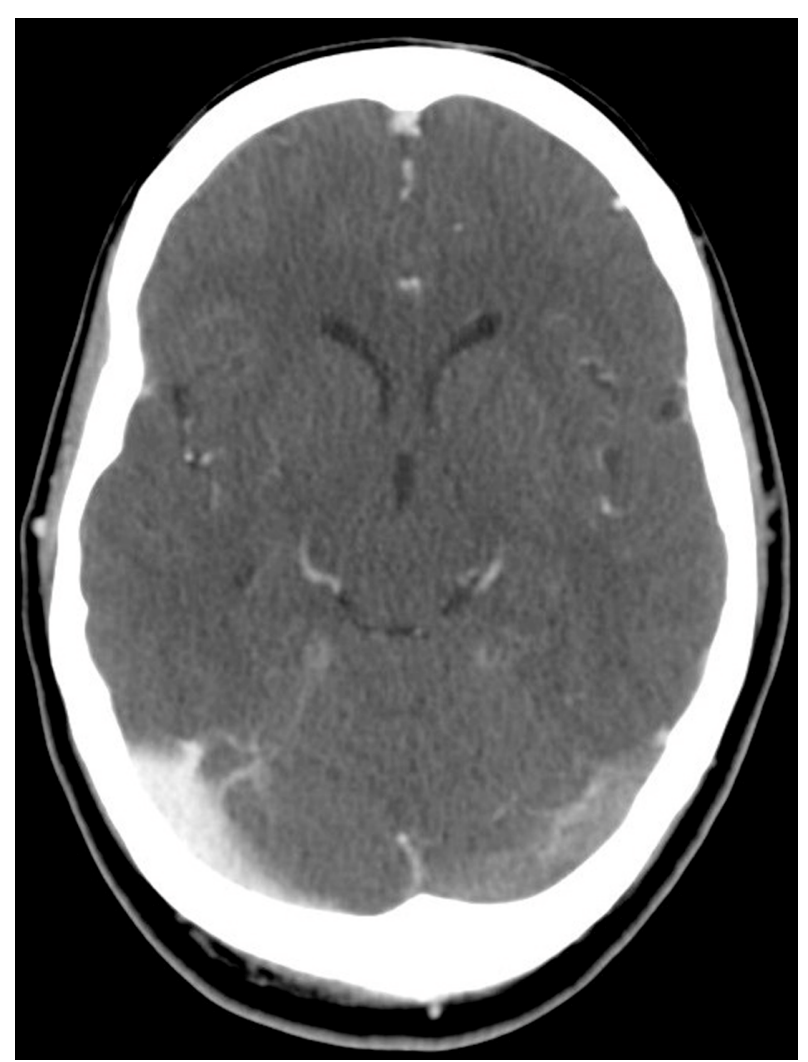

Figure 2 Contrast enhanced computed axial cranial tomography. 


\section{BMJ Case Reports}

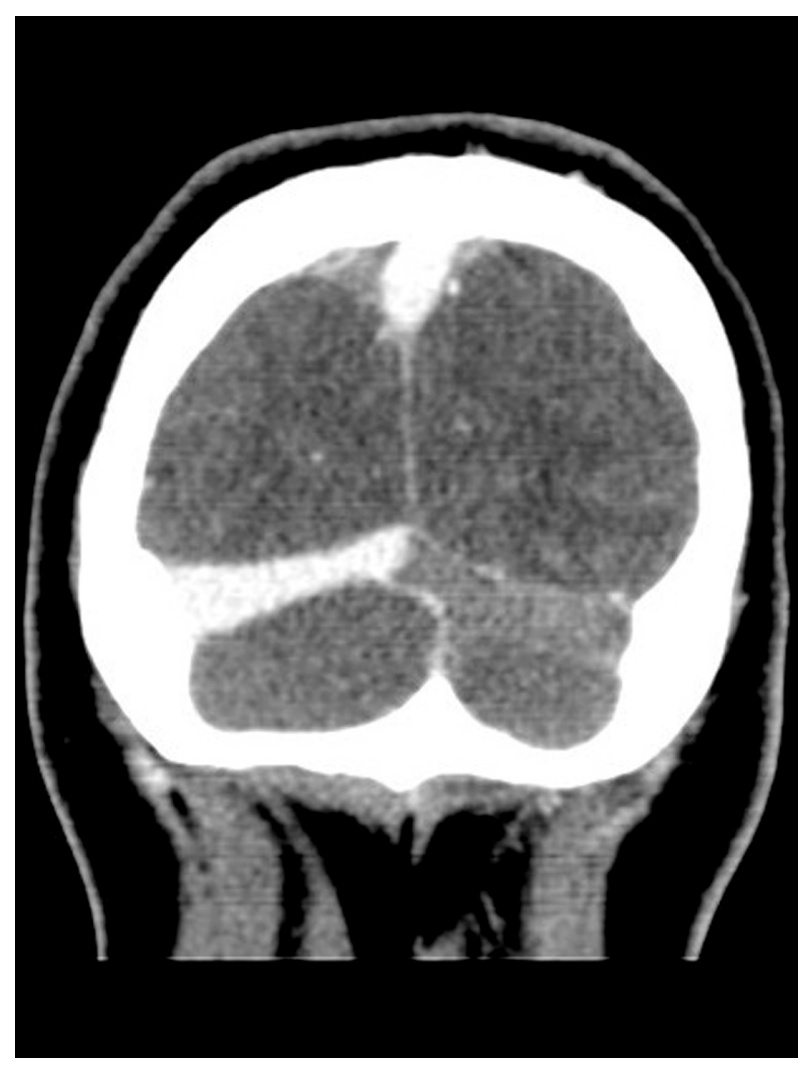

meningitis are included in the differential diagnosis of persistent headache in the puerperium. The hypercoagulable state of pregnancy predisposes women to cerebral thrombosis. Sinus venous thrombosis often occurs in young people, it is a rare subtype of stroke with a difficult diagnosis and an unknown incidence. The treatment with heparin in the acute phase is safe and is likely to improve its outcome. Postdural puncture headache is suspected with the combination of headache, pregnancy and dural puncture but this is not the only cause of such a headache, further investigations are necessary with the lack of response to postural treatment in postpartum headache.

\section{Competing interests None.}

Patient consent Obtained.

Figure 3 Contrast enhanced computed sagittal cranial tomography. Contrast-enhanced sagittal CT with the 'empty delta sign'.

This pdf has been created automatically from the final edited text and images.

Copyright 2010 BMJ Publishing Group. All rights reserved. For permission to reuse any of this content visit http://group.bmj.com/group/rights-licensing/permissions. BMJ Case Report Fellows may re-use this article for personal use and teaching without any further permission.

Please cite this article as follows (you will need to access the article online to obtain the date of publication).

Estella A, Payares JL. Postpartum headache: sinus venous thrombosis. BMJ Case Reports 2010;10.1136/bcr.06.2009.1936, date of publication

Become a Fellow of BMJ Case Reports today and you can:

- Submit as many cases as you like

- Enjoy fast sympathetic peer review and rapid publication of accepted articles

- Access all the published articles

- Re-use any of the published material for personal use and teaching without further permission

For information on Institutional Fellowships contact consortiasales@bmjgroup.com

Visit casereports.bmj.com for more articles like this and to become a Fellow 